\title{
Are Exports Productivity Enhancing? A Panel Analysis of Sub-Sahara Africa
}

\section{Olumuyiwa Olamade*, Oluwasola Oni}

Department of Economics, College of Social and Management Sciences, Caleb University Imota, Lagos, Nigeria

Email address:

muyiwaolamade@gmail.com (O. Olamade),onioluwasola@yahoo.com (O. Oni)

${ }^{*}$ Corresponding author

\section{To cite this article:}

Olumuyiwa Olamade, Oluwasola Oni. Are Exports Productivity Enhancing? A Panel Analysis of Sub-Sahara Africa. International Journal of Economics, Finance and Management Sciences. Vol. 5, No. 2, 2017, pp. 113-120. doi: 10.11648/j.ijefm.20170502.15

Received: January 5, 2017; Accepted: January 19, 2017; Published: March 1, 2017

\begin{abstract}
This paper examines the long-run relationship between exports and economic growth in Sub-Sahara Africa (SSA) to ascertain, if and how, exports drives economic growth through the productivity channel as opposed to volume contribution of exports to gross domestic product (GDP). We sampled seven SSA countries for the study including six of the most competitive countries in SSA by the Global Competitiveness Report ranking. Applying the panel analysis framework to a data set spanning 1987 to 2014, we found cointegration among non-exports GDP, gross capital formation, human capital, exports and imports. Estimates of the parameters of the cointegrating equation show a significant negative relationship between nonexports GDP and exports, suggesting that exports are productivity reducing in the long-run. However, there is a significant bidirectional causality between exports and economic growth. We conclude that, the dynamic effects of exports on growth through an economy-wide productivity increase are best achieved with the industrial sector as the leading exports sector.
\end{abstract}

Keywords: Exports, Growth, Long-Run, Sub-Sahara Africa, Productivity

\section{Introduction}

Both theoretical and empirical research largely supports the proposition that shifts from inward orientation policies characterised by stringent trade restrictions toward economic openness generates economic growth. High and sustained economic growth in developing economies reduces poverty, generate employment opportunities, and improve citizens' quality of life $[1,2]$. Policy makers and academics since the early 1960s have shown great interest in the possible relationship between exports and economic growth. One of the major driving force for this interest is the slower growth and accelerated inflation experienced by Latin America countries under the regime of import-substitution [3]. The economic success of Japan following the World War II, as well as the success of the outward-oriented policies of the East Asian Tigers [4] provides further motivation to investigate the causal relationship between exports and economic growth. The outcome of most of these investigations provides strong support for a policy shift in favour of export-led growth (ELG). Consequently, export-led growth became a major influence on policies of the World
Bank, and the standard model of development recommended by the IMF to all its client countries [4].

Empirical literature on the exports - economic growth nexus have come up with four propositions. First, is the notion that export expansion leads to economic growth causing capital efficiency and economies of scale, among others positive effects. This is the export-led growth hypothesis. The second is based on the idea that economic growth induces exports expansion. This is the growth-driven export hypothesis. These two propositions, according to [5], are not mutually exclusive; therefore, the third proposition suggests a feedback relationship between exports and economic growth, and the fourth a potential for a simple concurrent relationship between exports and economic growth.

In the last two decades, Sub-Saharan African (SSA) countries have witnessed high and sustained economic growth largely driven by investments in mining activities, infrastructure for transport and communication, and energy production [6]. This strong economic performance responds to export promotion industrialisation strategies, among other reforms, pursued in SSA countries. From the standpoint of 
developing countries, there are several theoretical arguments supporting the export-led growth hypothesis. On the demand side, export markets enable domestic output growth through an expansion of aggregate demand [7]. Similarly, export markets facilitate large-scale operations that allow developing countries to benefit from economies of scale [8, 9], increase productivity, and positive externalities on the non-export sector [10] resulting in economy-wide productivity boost.

Several other literatures, however has argued that the positive productivity effects predicted by the export-led growth hypothesis may not necessarily follow in developing countries. Some of the reasons adduced include the heavy dependence of many developing countries on primary commodity exports, which shift investment away from competitive manufacturing sectors where many positive externalities required for sustainable growth are generated $[11,12]$. Moreover, exports of primary goods tend to be subject to large price and volume shocks that may lead to increased macroeconomic uncertainty [13]. It is also argued that the non-export sector utilising very low production technology and low-skilled workers may be unable to make effective use of potential knowledge spillovers from the export sector.

Largely, empirical results remain mixed for both developed and developing countries and there is need to continue to investigate this subject especially in developing countries. Africa remains one of the world's poorest continents notwithstanding its strong economic performance in the last two decades. Improving on human development indices, infrastructural renewal, and diversification of earning base depends critically on foreign exchange earnings through exports.

\section{Empirical Review}

Export-led growth hypothesis has been the subject of a vast number of empirical studies using different estimation techniques. [14] divided these studies into four groups drawing from [15] and [16]. The first group includes crosscountry studies based on rank correlation coefficients $[17,18$, 19, 20], and ordinary least squares [3, 21, 22, 23]. These studies support a positive correlation between exports and output growth, and report the causal relationship as running from export to output growth. [24] is an exception in this group. He found no evidence to support export-led growth. Studies in this group are criticised on two major fronts. First, they ignore the fact that a positive correlation between exports and output growth can also suggest causality running from output growth to export. Second, cross-country analysis ignores the shifts in the relationship between variables within a country over time such that country-specific factors that may cause differences in the effect of exports on growth across countries. To address these criticisms, time-series data were analysed for the subsequent studies.

The second group of studies investigates the causal relationship between export growth and output for individual countries using [25] or [26] causality tests. In this category, [27] in a study of 16 industrial countries found support for bidirectional causality in only two countries (US and Norway). [28] found evidence for export-led growth in four of the 37 developing countries analysed. Other mixed results include [29, 30, and 31]. However, [32] in a sample of eight newly industrialised countries found evidence for strong reciprocal causality between export and industrial development in seven countries. The aforementioned studies based on the standard Granger causality tests did not examine whether exports and output are cointegrated. Some other studies in this group test for the long-run relationship between exports and output for individual countries using cointegration techniques. Among these are [33, 34, 35 and 36]. Results obtained generally suggest the existence of longrun relationship between exports and economic growth with causality running from exports to economic growth or in both directions.

The fourth group of studies used panel cointegration methods to test for a long-run relationship between exports and output. Panel tests have the advantage of higher test power due to their utilisation of both the time-series and cross-sectional dimensions of data sets. Panel tests thus correct for the low power of tests arising from small sample size associated with the use of individual country time series data. There are four studies in this group, which produced mixed results. To [37] and [38] economic growth drives exports with unidirectional long-run causality from economic growth to exports. On the contrary, [39] concluded that exports expansion are the cause of economic growth, while [40] finds support for positive long-run bidirectional effects between exports and economic growth. As pointed out by [14], the methods used in these studies did not take into account the potential cross-sectional dependence, which could lead to bias in results. Most importantly, [37, 38, 40], and numerous other studies do not control for the simultaneity bias associated with the fact that exports are themselves a component of GDP. As a result, the positive correlation may emerge simply because exports are part of GDP rather than because of any extra contribution that exports make to GDP or vice versa. Finally, these cointegration studies only examine the long-run relationship between exports and output and did not account for possible differences between the long-run and short-run effects of exports.

Recent studies focusing on Africa, like in other regions of the world, have come up with mixed results. [41] based on the threshold regression procedure, and [42] using panel data analysis find support for export-led growth. However, [43] found bidirectional causality between non-oil exports and economic growth for a group of countries. [44] found causality from capital goods imports to growth in 35 SSA countries in support of the import-led growth hypothesis. Capital goods imports, especially, from the technologically advanced countries embodies latest technological knowledge and thus enhances productivity in the export sector of developing countries. [6] in his study of three SSA countries using panel data approach validates the export-led growth strategy in SSA. These studies also suffer from the 
simultaneity bias associated with the inclusion of exports in the GDP. Their conclusions derive from the effects of exports share of GDP and not on the productivity effect of exports on GDP. This current study adopts the approach that separates exports from the GDP, so that outcomes derive from the effects of exports expansion on the GDP through the productivity channel. Following [14], we investigate the effects of exports on growth through the productivity side rather than the sheer volume of exports in GDP as is common with most of the works on this subject. Thus, we use nonexport GDP (GDP less exports of goods and services) instead of export-inclusive GDP to control for the simultaneity between exports and output arising from exports being part of output. The rest of the paper is structured as follows. Section 2 describes the data and sets out the empirical model. Section 3 presents the econometrics methodology. We report the empirical results in sections 4 , and conclude with some policy recommendations in section 5 .

\section{Data Description, Variables and Model}

We select the most competitive SSA countries based on the 2015-2016 edition of the Global Competitiveness Report (GCR). The GCR is a publication of the World Economic Forum that computes annual index of competitiveness across countries and regions of the world based on some static and dynamic components that determines a country's level of productivity. The level of productivity in turn sets the level of prosperity that the country can attain as well as its growth potential. The report classified countries into three categories in the order of sophistication or stage of development as; factor-driven economies, efficiency-driven economies and innovation-driven economies. Economies are also classified as being in transition between the three stages. For the purpose of this study, all the seven SSA countries identified from the GCR (2015-2016) as having passed the factordriven stage of development are selected for inclusion in our sample. The countries are Mauritius (in transition from efficiency-driven to innovation-driven stage), Cape Verde (efficiency-driven stage), Namibia (efficiency-driven stage), South Africa (efficiency-driven stage), Swaziland (efficiency-driven stage), Botswana (efficiency-driven stage), Nigeria (in transition from factor-driven to efficiency-driven stage), Gabon (in transition from factor-driven to efficiencydriven stage). However, for lack complete of data to fit our variables and the study period, we drop Cape Verde from the sample and include Kenya, the best performer of the factordriven economies. Country data spanning 1987 to 2014 were extracted from the World Development Indicators 2015 in constant local currency. The selection of sample period was determined by the availability of continuous data for the variables and countries selected. The final sample thus includes six of the most seven competitive SSA countries and Kenya.

Following [14], we specify the production function in equation (1) to capture the impact of exports on output through the productivity channel as opposed to the share of exports in output:

$$
\mathrm{Y}_{\mathrm{it}}=\mathrm{A}_{\mathrm{it}} \mathrm{K}_{\mathrm{it}}
$$

where $Y_{i t}$ is the output of country $i$ at time $t$ as measured by its real GDP, $K_{i t}$ is the capital of country $i$ at time $t$ approximated by its gross capital formation (GCF), and $A_{i t}$ is a productivity parameter. To check the effects of exports on economic growth through changes in productivity, we assume that the productivity parameter, $A_{i}$ can be expressed as a function of exports, $X_{i t}$ as:

$$
A_{i t} f X_{i t}=\mathrm{X}_{\mathrm{it}}^{2 \mathrm{bi}}
$$

Combining equations (1) and (2) and taking the natural logarithms yields:

$$
\operatorname{In}\left(Y_{i t}\right)=\alpha_{1 i} \ln \left(K_{i t}\right)+\alpha_{2 i} \operatorname{In}\left(X_{i t}\right)
$$

where the coefficients $b_{1 i}$ and $b_{2 i}$ denote the cross-country averages of the elasticities of output with respect to capital and exports, which are allowed to be country specific and thus to vary across countries. However, the estimate of $b_{2 i}$ cannot be used to measure the average productivity effect of exports on output, since exports are a part of output via the national accounting identity. If not separated, a positive and significant relationship between exports and output is almost inevitable even if there are no productivity effects. We therefore separate the impact of exports on output by considering real non-exports output, $N_{i t}=Y_{i t}-X_{i t}$. By replacing the logarithm of total output, $\operatorname{In}\left(Y_{i t}\right)$, with the logarithm of non-export output, $\operatorname{In}\left(N_{i t}\right)$, we obtain:

$$
\operatorname{In}\left(N_{i t}\right)=\beta_{1 i} \operatorname{In}\left(K_{i t}\right)+\beta_{2 i} \operatorname{In}\left(X_{i t}\right)
$$

The coefficient $\beta_{2 i}$ in equation (4) is zero, if the coefficient of the export variable in the augmented production function specification in equation (3) just reflects the share of exports in output. On the other hand, if $\beta_{2 \mathrm{i}}>0$ the growth effect of exports goes beyond the mere increase in export volume suggesting that exports increase output through increased productivity. Where $\beta_{2 \mathrm{i}}<0$, exports contribute less to GDP growth than the increase in export volume, suggesting that exports are productivity-reducing.

Though [14] excluded imports in their model arguing that the productivity effect of exports that operates via imports is omitted if export earnings are used to finance imports. However, we include imports as a proxy for knowledge spillover or technology transfer associated with imports, which are believed to incorporate knowledge of foreign technology and production know-how essential for boosting productivity in the export sector. Endogenous growth models show that imports can stimulate long-run economic growth because they offer domestic firms access to foreign knowledge [45]. Thus, imports in developing countries play a similar role to that of R\&D activities in developed countries, as sources of technology-intensive intermediate factors of production [46, 47, 48].

Nevertheless, even if developing countries import foreign technologies, it has been argued that a certain level of 
technology and human capital in the exports sector may be necessary to acquire the foreign technology, as well as ability on the part of the non-exports sector to make effective use of knowledge spill-overs from the export sector. Given that the exports sector possesses the necessary human capital to acquire foreign technology and the non-exports sector the ability to effectively use knowledge spill-over from the exports sector, the exports sector via increased productivity becomes an engine of growth. Thus, we approximate human capital using scientific and technical journal articles for the reason that data on secondary school enrolment or completion often used as a proxy for human capital are either not available or grossly incomplete for most of the countries in our sample.

We complete the specification of the model by adding to equation (4) the natural logarithms of imports, and scientific and technical journal articles as $\operatorname{In}\left(\mathrm{M}_{i t}\right)$ and $\operatorname{In}\left(\mathrm{H}_{i t}\right)$, respectively, as well as the error term $\left(\varepsilon_{i t}\right)$, to obtain:

$$
\operatorname{In}\left(N_{i t}\right)=\beta_{1 i} \operatorname{In}\left(K_{i t}\right)+\beta_{2 i} \operatorname{In}\left(X_{i t}\right)+\beta_{3 i} \operatorname{In}\left(M_{i t}\right)+\beta_{4 i} \operatorname{In}\left(H_{i t}\right)+\varepsilon_{i t}
$$

where;

$N_{i t}=$ non-exports GDP, country i, time t

$K_{i t}=$ gross capital formation (GCF) country i, time $\mathrm{t}$

$X_{i t}=$ exports of goods and services (EXP) country i, time $\mathrm{t}$

$M_{i t}=$ imports of goods and services (IMP) country $\mathrm{i}$, time $\mathrm{t}$

$H_{i t}=$ human capital (HCP) country $\mathrm{i}$, time $\mathrm{t}$

\section{Estimation Technique}

The objective of this paper is to examine the long-run and dynamic causal relationship of economic growth measured as non-export GDP $\left(\mathrm{N}_{\mathrm{it}}\right)$ and $\mathrm{K}_{\mathrm{it}}(\mathrm{GCF}), \mathrm{X}_{\mathrm{it}}(\mathrm{EXP}), \mathrm{M}_{\mathrm{it}}(\mathrm{IMP})$ and $\mathrm{H}_{\mathrm{it}}$ (HCP). Our analysis is based on most recent panel tests. Panel tests exploit both the time series and cross-sectional dimension of the data, and are more powerful than conventional time series unit root and cointegration tests. Panel tests start with the decomposition of each variable into common and individual factors. The common unit root test is based on [49]. The [50] as well as the Fisher-ADF, and FisherPP tests provide results for the individual unit root tests. To reject the null hypothesis of a unit root, both the common factors and the individual factors must be $I(1)$. We use the [51, 52] and [53] to test for a long-run relationship. [51] and [52] separately checks cointegration for the common and individual factors. The presence of cointegration requires that we reject the null hypothesis of no cointegration for both the common and the individual factors. For [54]'s cointegration test, the null hypothesis of no cointegration is not valid if the ADF statistic is significant at the conventional levels.

Once the variables are cointegrated, we proceed to estimate the parameters of the cointegrating equation. For this purpose, we use the panel fully modified OLS (FMOLS) and dynamic OLS (DOLS). [54] showed that the FMOLS exhibits small sample bias, which does not apply in DOLS. The point estimates of DOLS provide a more useful interpretation in the case of heterogeneous cointegrating vectors, and can be interpreted as the mean value of the cointegrating vectors. Moreover, the leads and lags differences account for possible serial correlation and endogeneity of the independent variables, implying that the DOLS procedure generates unbiased estimators for variables that cointegrate even with endogenous independent variables.

Finally, we estimate a panel pairwise granger causality between the variables to determine the direction of causality between each pair of variables in the panel. The Granger causality test is based on the level of significance of the probability value of the $F$-Statistic. If the probability value of the $F$-Statistic is less than 0.10 , then there exists a Granger causality between the tested variables. If one of the pairs is significant, there is a uni-directional causality. A bidirectional causality exists, running from each of the variable to the other, if the two tested variables are significant. There is no causal relation between any pair of variables if both variables are insignificant.

\section{Empirical Results and Discussion}

\subsection{Unit Root Tests}

The panel unit root tests reported in Table 1 shows that the common and individual components of the panel are nonstationary in level, so we accept the null hypothesis of unit root. At first difference all variables in the two components are stationary. We may conclude that each variable in the model is integrated of order one. By these results, we proceed to test for cointegration.

Table 1. Results from panel unit root test.

\begin{tabular}{|c|c|c|c|c|c|c|c|c|}
\hline \multicolumn{3}{|c|}{ Common unit root test } & \multicolumn{6}{|c|}{ Individual unit root tests } \\
\hline \multicolumn{3}{|c|}{ Levin, Lin \& Chu } & \multicolumn{2}{|c|}{ Im, Pesaran \& Shin } & \multicolumn{2}{|c|}{ ADF-Fisher** Chi-square } & \multicolumn{2}{|c|}{ PP-Fisher** Chi-square } \\
\hline Variable & Statistic & Prob. & Statistic & Prob. & Statistic & Prob. & Statistic & Prob. \\
\hline \multicolumn{9}{|l|}{ Level } \\
\hline In $\mathrm{N}_{\mathrm{it}}$ & -0.47167 & 0.3186 & 1.60634 & 0.9459 & 15.6497 & 0.3352 & 10.1536 & 0.7509 \\
\hline In $K_{i t}$ & 0.48618 & 0.6866 & 1.97539 & 0.9759 & 6.17238 & 0.9620 & 9.96147 & 0.7650 \\
\hline $\mathrm{In} \mathrm{H}_{\mathrm{it}}$ & 1.60951 & 0.9462 & 3.64004 & 0.9999 & 3.32222 & 0.9984 & 4.17721 & 0.9943 \\
\hline In $X_{i t}$ & -2.08175 & 0.0187 & -0.11612 & 0.4538 & 15.7001 & 0.3320 & 12.3928 & 0.5748 \\
\hline \multicolumn{9}{|c|}{$1^{\text {st }}$ Difference* } \\
\hline In $\mathrm{N}_{\mathrm{it}}$ & -9.44509 & 0.0000 & -9.47793 & 0.0000 & 99.7707 & 0.0000 & 106.671 & 0.0000 \\
\hline In $K_{i t}$ & -9.08637 & 0.0000 & -10.2728 & 0.0000 & 109.502 & 0.0000 & 131.778 & 0.0000 \\
\hline $\mathrm{In} \mathrm{H}_{\mathrm{it}}$ & -13.7847 & 0.0000 & -13.7823 & 0.0000 & 142.539 & 0.0000 & 156.083 & 0.0000 \\
\hline
\end{tabular}




\begin{tabular}{|c|c|c|c|c|c|c|c|c|}
\hline \multicolumn{3}{|c|}{ Common unit root test } & \multicolumn{6}{|c|}{ Individual unit root tests } \\
\hline \multicolumn{3}{|c|}{ Levin, Lin \& Chu } & \multicolumn{2}{|c|}{ Im, Pesaran \& Shin } & \multicolumn{2}{|c|}{ ADF-Fisher** Chi-square } & \multicolumn{2}{|c|}{ PP-Fisher** Chi-square } \\
\hline Variable & Statistic & Prob. & Statistic & Prob. & Statistic & Prob. & Statistic & Prob. \\
\hline In $X_{i t}$ & -9.69774 & 0.0000 & -8.90756 & 0.0000 & 94.9947 & 0.0000 & 119.001 & 0.0000 \\
\hline In $\mathrm{M}_{\mathrm{it}}$ & -10.5348 & 0.0000 & -9.77146 & 0.0000 & 102.249 & 0.0000 & 107.160 & 0.0000 \\
\hline
\end{tabular}

Null hypothesis: Unit root

*Test values are significant at 0.01 level

**Probability for Fisher tests computed using an asymptotic Chi-square distribution. All other tests assume asymptotic normality

Automatic lag length based on SIC

\subsection{Cointegration Test}

Table 2. Results from panel cointegrated test.

\begin{tabular}{|c|c|c|c|c|c|}
\hline \multicolumn{6}{|c|}{ Pedroni Residual Cointegration Test } \\
\hline Panel (within dimension) & & & Group (between & & \\
\hline \multicolumn{6}{|c|}{ No deterministic intercept or trend } \\
\hline Statistic & Value & Prob. & Statistic & Value & Prob. \\
\hline Panel PP-Stat. & -3.052321 & $0.0011^{*}$ & Group PP-Stat. & -2.758924 & $0.0029 *$ \\
\hline $\begin{array}{l}\text { Panel ADF-Stat. } \\
\text { No deterministic trend }\end{array}$ & -3.153835 & $0.0008^{*}$ & Group ADF-Stat. & -2.587617 & $0.0048^{*}$ \\
\hline Panel PP-Stat. & -2.204898 & $0.0137 * *$ & Group PP-Stat. & -2.528184 & $0.0057 *$ \\
\hline Panel ADF-Stat. & -2.686939 & $0.0036^{*}$ & Group ADF-Stat. & -3.397976 & $0.0003 *$ \\
\hline \multicolumn{6}{|c|}{ Kao Residual Cointegration Test } \\
\hline $\mathrm{ADF}$ & -5.453858 & $0.0000^{*}$ & & & \\
\hline
\end{tabular}

Null hypothesis: No cointegration

*and ** Test values are significant at 0.01 and 0.05 level respectively

Automatic lag length based on SIC

Going by the results of the two cointegration tests in Table 2, we fail to accept the null hypothesis that assumes no longrun relationship among the variables in the panel. At 0.05 level of significance, we can assume that the variables in the panel cointegrate. There is thus a long-run relationship dependent variable and the regressors. We can now obtain a meaningful estimate of the parameters of the cointegrating equation in the panel framework. Results of the long-run estimates of the cointegrating equation are shown in Table 3.

\subsection{Long-Run Elasticities}

The FMOLS and DOLS estimations of the coefficients $\mathrm{K}_{\mathrm{it}}$
(GCF), $\mathrm{H}_{\mathrm{it}}(\mathrm{HCP})$, and $\mathrm{M}_{\mathrm{it}}$ (IMP) are positive and statistically significant. Contrary to our expectation, $\mathrm{X}_{\mathrm{it}}(\mathrm{EXP})$ is negative though statistically significant. Going by the more robust DOLS, exports appears to be the most important factor explaining growth, albeit in the opposite direction. On the average, a one percent increase in exports reduces growth by about 0.48 percent in the seven countries. A one percent increase in imports and human capital each enhances growth by about 0.30 percent. The long-run relationship between gross capital formation and growth indicates that one percent rise in gross capital formation increases growth by 0.25 percent.

Table 3. Results from Panel FMOLS and DOLS estimation.

\begin{tabular}{|c|c|c|c|c|c|c|}
\hline \multicolumn{7}{|c|}{ Panel Long-Run Elasticity } \\
\hline & FMOLS & & & DOLS & & \\
\hline Variable & $\mathbf{B}_{\mathrm{i}}$ & t-Stat. & Prob*. & $\mathbf{B}_{\mathrm{i}}$ & t-Stat. & Prob*. \\
\hline $\operatorname{InK}_{\mathrm{it}}$ & 0.376420 & 6.356757 & 0.0000 & 0.254588 & 3.354052 & 0.0013 \\
\hline $\mathrm{InH}_{\text {it }}$ & 0.261787 & 9.461212 & 0.0000 & 0.299110 & 9.448037 & 0.0000 \\
\hline $\operatorname{In} \mathrm{X}_{\mathrm{it}}$ & -0.366674 & -.4 .227334 & 0.0000 & -0.475666 & -4.744416 & 0.0000 \\
\hline $\mathrm{InM}_{\mathrm{it}}$ & 0.217840 & 2.885380 & 0.0044 & 0.304306 & 3.369876 & 0.0012 \\
\hline
\end{tabular}

Fixed leads and lags specification (lead $=1$, lag $=1$ )

*Test values are significant at 0.01

The export-led growth hypothesis predicts that exports increase output through increased productivity. That is, exports generally contribute more to GDP growth than the sheer change in export volume. Thus, the hypothesis is valid if the exports coefficient in the estimated equation (equation 5 ) is positive and significant. Our result negates the exportled growth hypothesis. Non-export output decreases by 0.48 percent for every one percent increase in exports suggesting that exports are productivity-reducing in the long-run. This result may find an explanation in the literature that supports the view that the positive productivity effect predicted by the export-led growth hypothesis does not necessarily occur in developing countries. First, because exports increase productivity by concentrating investment in the sector in which an economy has a comparative advantage [55], increased exports of primary products in which most 
developing countries, including those in our sample, have a comparative advantage may shift investment away from competitive manufacturing sectors. According to $[11,12]$ the primary exports sector by its nature does not have many linkages with and spill-overs into the economy as compared with manufacturing. Second, with limited spill-overs from exports sector into the economy, the incentives of the nonexport sectors for technological improvements, labour training and more efficient management is abridged. As a result, the non-export sectors depend essentially on low production technology and low-skilled workers causing economy-wide productivity loss. Third, severe factor market imperfections in developing countries that limits the mobility of factors between sectors and the flexibility of factor prices may with an increase in exports result in unemployment or under-employment, and as a consequence, in productivity losses [56, 57].

This work includes imports in the estimated model as a proxy for knowledge spillover or technology transfer. Endogenous growth models show that imports can stimulate long-run economic growth because they offer domestic firms access to foreign knowledge and production know-how essential for boosting productivity [47, 48]. By our results, imports appear more productivity enhancing in SSA than exports and may serve to confirm the view that imports in developing countries play a role similar to that of $R \& D$ activities in developed countries, as sources of technologyintensive intermediate factors of production [46]. However, a report by [58] found little evidence to support the claim that improved access to imported inputs has significantly resulted in progress for industrialization and productivity in Africa, thus suggesting that African countries are increasingly connected to the global value chains largely as suppliers of primary or other low-end products. Though, imports appears to be more productivity enhancing than exports, this study cannot establish a case for import-led growth in SSA as our causality test will show in Table 4. Interestingly, human capital growth in the seven countries is not responsive to changes in any of the variables in the model. In the same vein, changes in human capital do not influence growth in any of the other variables. There is no causality relationship between human capital and all other variables in the model. Similarly, there appears to be no causality between nonexport GDP and gross capital formation.

\subsection{Panel Granger Causality Test}

Table 4. Results from pairwise Granger causality test.

\begin{tabular}{|c|c|c|c|c|c|}
\hline \multicolumn{6}{|c|}{ Pairwise Granger Causality } \\
\hline & InN $N_{\text {it }}$ & Ink $_{\text {it }}$ & $\mathrm{InH}_{\mathrm{it}}$ & InE $_{\text {it }}$ & InM $_{\text {it }}$ \\
\hline $\mathrm{InN}_{\mathrm{it}}$ & - & $2.60141(0.1085)$ & $0.14413(0.7047)$ & $6.39938(0.0123)^{*}$ & $9.92201(0.0019)^{*}$ \\
\hline $\mathrm{Ink}_{\mathrm{it}}$ & $1.90143((0.1696)$ & - & $0.02350(0.8783)$ & $3.48434(0.0636)^{* *}$ & $3.03356(0.0832)^{* *}$ \\
\hline $\mathrm{InH}_{\mathrm{it}}$ & $0.01478(0.9034)$ & $0.32567(0.5689)$ & - & $0.10007(0.7521)$ & $1.28456(0.2586)$ \\
\hline $\mathrm{InE}_{\mathrm{it}}$ & $5.71017(0.0179)^{*}$ & $13.7052(0.0003)^{*}$ & $0.28644(0.5932)$ & - & $4.42557(0.0368)^{*}$ \\
\hline $\operatorname{InM}_{\mathrm{it}}$ & $1.27283(0.2607)$ & $4.26912(0.0402)^{* *}$ & $0.41944(0.5181)$ & $3.09691(0.0801)^{* *}$ & - \\
\hline
\end{tabular}

Lags: 1

*and** Test values are significant at 0.05 and 0.10 level respectively

We found a unidirectional causality running from nonexport GDP to imports, suggesting that economic growth drives expansion in imports. There is however, bidirectional causality between non-export GDP and exports; gross capital formation and exports; gross capital formation and imports, and between exports and imports.

Thus, there is evidence that in the short-run exports and non-export GDP are mutually reinforcing, suggesting that export growth leads to growth in non-export GDP, which in turn leads to an increase in exports. Whereas, exports exhibit negative dynamic effects on non-export GDP in the long-run, signifying that exports are productivity reducing in the longrun. Exports expansion does not generate growth working through the productivity channel.

\section{Conclusion and Policy Implication}

This paper examines the long-run dynamic productivity effects of exports on non-export GDP. The export-led growth hypothesis, in its original form, holds that exports have an indirect effect on output through the productivity channel. Considering the real GDP net of exports, the exports-led growth hypothesis as a development strategy is valid if the exports coefficient of the estimated model is positive and significant. The results obtained for the seven countries in this study negate the exports-led growth hypothesis in SSA. While there is a bi-directional causality between non-exports GDP and exports, the long-run dynamics show that exports are productivity-reducing. This result is consistent with [14]. They found a negative but significant long-run relationship between exports and non-exports GDP in a sample of 45 developing countries selected across North Africa, SSA, South America, Central America and the Caribbean, East Asia and South Asia. [14] found the same result even when countries from each region are successively excluded from the sample, suggesting that regardless which of the regions is excluded from the sample, the long-run relationship between exports and non-export GDP remains negative and highly significant.

The implication of this outcome is that the effect of exports on non-export output is generally productivityreducing in developing countries. At the level of policy, this is not to say that exports are bad for developing countries. Rather, exports may effectively serve as an engine of growth 
if the exports sector is: (i) the most efficient sectors of the economy, (ii) have extensive linkages with, and spill-over into the economy resulting in economy-wide productivity increase, and (iii) generate externalities required for sustainable growth in the economy. Primary products, which currently leads the exports sectors in SSA, by nature, does not have the required linkage with the rest of the economy, and cannot therefore generate the knowledge spill-overs necessary to drive an economy-wide productivity increase, which in turn drives output growth. The current drive to diversify the earnings base of most economies in the SSA, especially the oil-rich countries, should include a deliberate policy on the development of an outward-oriented industrial sector with a concomitant infrastructural base to enhance the efficiency of the industrial sector. A value chain approach to industrial development will ensure that the necessary linkages and positive spillovers associated economy-wide productivity growth are created.

\section{References}

[1] Squire, L. (1993). Fighting Poverty. American Economic Review Paper and Proceedings, 83 (2), 377-382.

[2] Esterly, W. (2002). Inequality Does Cause Underdevelopment, Centre for Global Development Working Paper, 1. Washington, D. C.

[3] Balassa B, (1978) Exports and economic growth: further evidence. Journal of Development Economics, 5, 181-189.

[4] Palley, T. I. (2003) Export-Led Growth: Evidence of Developing Country Crowding-out. In Arestis, Baddeley, \& McCombie (Eds). Economic Integration, Regionalism, and Globalization, Cheltenham: Edward Elgar.

[5] Kónya L. (2004). Export-Led Growth, Growth-Driven Export, Both Or None? Granger Causality Analysis on OECD Countries. Applied Econometrics and International Development. Aeeade. 4-1.

[6] Chia, Y. E. (2015). Exports-led growth hypothesis: empirical evidence from selected African Countries. Procedia Economics and Finance, 35, 232-240.

[7] Siliverstovs, B. \& Herzer, D. (2007). Manufacturing exports, mining exports, and growth: cointegration and causality analysis for Chile (1960-2001). Applied Economics, 39, 153-167.

[8] Helpman, E. \& Krugman, P. (1985). Market structure and foreign trade. MIT Press, Cambridge, Mass.

[9] Ray, S. (2011). A causality analysis on the empirical nexus between export and economic growth: evidence from India. International Affairs and Global Strategy, 1, 24-38.

[10] Feder, G. (1983). On exports and economic growth. Journal of Development Economics, 12, 59-73.

[11] Sachs, J. \& Warner, A. (1995). Natural resource abundance and economic growth. NBER Working Paper, 5398.

[12] Herzer, D. (2007). How does trade composition affect productivity? Evidence for Chile. Applied Economics, Letters 14, 909-912.
[13] Dawe, D. (1996) A new look at the effects of export instability on investment and growth. World Development, 24, 19051914.

[14] Dreger, C. \& Herzer, D. (2012). A further examination of the export-led growth hypothesis. FIW Working Paper, 84.

[15] Edwards S (1993) Openness, trade liberalisation, and growth in developing countries. Journal of Economics Literature, 31, 1358-1393.

[16] Giles, J A \& Williams CL (2000). Export-led growth: a survey of the empirical literature and some non-causality results. Part 1. Journal of International Trade and Economic Development 9: 261-37.

[17] Kravis, I. B. (1970). Trade as a handmaiden of growth: Similarities between the nineteenth and twentieth centuries, Economic Journal, 80 (320), 850-72.

[18] Michaely, M. (1977) Exports and growth: an empirical investigation. Journal of Development Economics, 4, 49- 53.

[19] Bhagwati, J. (1978). Anatomy and Consequences of Exchange Control Regimes: Liberalization Attempts and Consequences. Cambridge, MA: Ballinger.

[20] Fajana O. (1979) Trade and Growth: The Nigerian Experience. World Development, 7, 73-78.

[21] Tyler, W. (1981). Growth and export expansion in developing countries: some empirical evidence. Journal of Development Economics, 9, 121-130.

[22] Heitger, B. (1987). Import protection and export performance: their impact on economic growth, Weltwirtschaffliches Archiv, 123 (2) 249-61.

[23] Lussier, M. (1993). Impacts of exports on economic performance: A comparative study", Journal of African Economies, 2 (1), 106-27.

[24] Colombatto, E. (1990). An analysis of exports and growth, Kyklos, 43 (4), 579-97.

[25] Granger, C. W. J. (1969). Investigating causal relationships by econometric models and cross-spectral methods. Econometrica, 37, 424-438.

[26] Sims, C. A. (1972). Money, income, and causality. American Economic Review, 62, 540-552.

[27] Afxentiou, P. C. \& Serletis, A. (1991). Exports and GNP Causality in the Industrial Countries: 1950-1985. Kyklos, vol. 44, pp. 167-79.

[28] Jung, W. S, \& Marshall, P. J. (1985) Exports, growth and causality in developing countries. Journal of Development Economics, 18, 1-12.

[29] Darrat, A. F. (1987). Are exports an engine of growth? Another look at the evidence", Applied Economics, 19, 2 (February): 277-83.

[30] Bahmani-Oskooee M., Mohtadi, H., \& Shabsigh, G. (1991) Exports, growth and causality: a re-examination. Journal of Development Economics, 36, 405-415.

[31] Dodaro, S. (1993) Exports and growth: a reconsideration of causality. Journal of Developing Areas, 27, 227-244. 
[32] Chow, P. C. Y (1987) Causality between export growth and industrial development: Empirical evidence from NICs. Journal of Development Economics, 26, 55-63.

[33] Bahmani-Oskooee M, \& Alse, J. (1993). Export growth and economic growth: An application of cointegration and error correction modelling. Journal of Developing Areas 27, 535-542.

[34] Love, J. \& Chandra, R. (2004) Testing export-led growth in India, Pakistan and Sri Lanka using a multivariate framework. Manchester School, 72: 483-96.

[35] Bahmani-Oskooee, M. \& Oyolola, M. (2007) Export growth and output growth: an application of bounds testing approach. Journal of Economics and Finance, 31, 1-11.

[36] Bahmani-Oskooee, M. \& Economidou, C. (2009). Export-led growth vs. growth-led exports: LDCs experience. Journal of Developing Areas, 42 (2), 179-212.

[37] Bahmani-Oskooee, M., Economidou, C, \& Goswami, G. G. (2005) Export-led growth hypothesis revisited: a panel cointegration approach. Sci J Admin Development 3, 40-55.

[38] Reppas, P. A, \& Christopoulos, D. K. (2005) The exportoutput growth nexus: evidence from African and Asian countries. Journal of Policy Modeling 27: 929-940.

[39] Parida, P. C., \& Sahoo, P. (2007). Export-led growth in South Asia: a panel cointegration analysis. International Economics Journal 21, 155-176.

[40] Jun, S. (2007). Bi-directional relationships between exports and growth: a panel cointegration analysis. Journal of Economic Research, 12, 133-171.

[41] Foster, N. (2006). Exports, growth and threshold effects in Africa. Journal of Development Studies 42, 1056-1074.

[42] Pazim, K. H. (2009). Panel data analysis of export-led growth hypothesis in BIMP-EAGA Countries. University Library of Munich, Germany.

[43] Mehrara, M. \& Firouzjaee, B. A. (2011). Granger causality relationship between export growth and GDP growth in developing countries: panel cointegration approach. International. Journal of Humanities Social Science, 1, 223-231.

[44] Bbaale, E. \& Mutenyo, J. (2011). Export composition and economic growth in Sub-Saharan Africa: a panel analysis. Consilience: The Journal of Sustainable Development. 6 (1), $1-19$.
[45] Grossman, G., \& Helpman, E. (1991). Innovation and Growth in the Global Economy. MIT Press, Cambridge, MA.

[46] Mazumdar, J. (2001). Imported machinery and growth in LDCs. Journal of Development Economics, 65, 209-224.

[47] Eaton, J., \& Kortum, S. (2001). Trade in capital goods. European Economic Review, 45, 1195-123.

[48] Caselli, F., \& Wilson, D. J. (2004). Importing technology. Journal of Monetary Economics, 51, 1-32.

[49] Levin, A., Lin C-F, and Chu, C-SJ (2002). Unit root test in panel data: asymptotic and finite-sample properties. Journal of Econometrics 108, 1-24.

[50] Im, K. S., Pesaran, M. H., \& Shin, Y. (2003). Testing for unit roots in heterogeneous panels. Journal of Econometrics, 115, $53-74$

[51] Pedroni, P. (2000). Fully modified OLS for the heterogeneous cointegrated panels. Advances in Econometrics, 15, 93-130.

[52] Pedroni, P., 2004. Panel cointegration: asymptotic and finite sample properties of pooled time series tests with an application to the PPP hypothesis. Econometric Theory, 20, 597-625.

[53] Kao, C. (1999). Spurious Regression and Residual-Based Tests for Cointegration in Panel Data. Journal of Econometrics, 90, 1-44.

[54] Kao, C. \& Chiang, M (2000). On the estimation and inference of a cointegrated regression in panel data. Advances in Econometrics, 15, 179-222.

[55] Kunst, R. M. and Marin, D. (1989). On exports and productivity: a causal analysis. Review of Economics and Statistics, 71, 699-703.

[56] United Nations Commission for Africa (2015). Economic Report on Africa 2015: Industrializing through trade. Addis Ababa.

[57] Edwards, S. (1988). Terms of trade, tariffs, and labor-market adjustment in developing countries. World Bank Economic Review, 2, 165-185.

[58] World Bank (2009). Doing business 2009. Coparing regulation in 181 economies. Working Paper No. 5398. Washington, D.C. 